\title{
WEIGHT-LENGTH RELATIONS FOR TEN DEMERSAL FISHES (ACTINOPTERYGII) FROM EASTERN KOREAN WATERS
}

\author{
Joo Myun PARK*, Hae Kun JUNG, and Chung Il LEE \\ Department of Marine Bioscience, Gangneung-Wonju National University, Gangneung, Korea
}

Park J.M., Jung H.K., Lee C.I. 2018. Weight-length relations for ten demersal fishes (Actinopterygii) from eastern Korean waters. Acta Ichthyol. Piscat. 48 (2): 209-211.

\begin{abstract}
This paper presents the relations between total length and weight for ten demersal fishes from eastern Korean waters: Alcichthys alcicornis (Steindachner 1881); Cleisthenes pinetorum Jordan et Starks, 1904; Dasycottus setiger Bean, 1890; Gadus macrocephalus Tilesius, 1810; Glyptocephalus stelleri (Schmidt, 1904); Gymnocanthus herzensteini Jordan et Starks, 1904; Gymnocanthus intermedius (Temminck et Schlegel, 1843); Liparis punctulatus (Tanaka, 1916); Lycodes tanakae Jordan et Thompson, 1914; and Pseudopleuronectes herzensteini (Jordan et Snyder, 1901). Fish samples were collected seasonally between 2011 and 2017 using bottom gill net and trammel net. The values of exponents $a$ and $b$ from the weight-length relations (WLRs) were estimated. The WLRs for A. alcicornis, G. herzensteini, G. intermedius, and L. punctulatus were estimated for the first time, and new maximum lengths were recorded for $G$. herzensteini and L. punctulatus. All the relations between total length and weight were statistically significant (all $r^{2}>0.937$ ). The values of exponent $b$, estimated using simple linear least squares of $\log _{10}$-transformed weight and length data, ranged from 2.899 to 3.416.
\end{abstract}

Keywords: WLRs, demersal fishes, gill net fisheries, Sea of Japan, East Sea

\section{INTRODUCTION}

Studies of morphometric relations are useful tools in fisheries research because they can identify and compare specific species, populations and stocks (King 1995, Froese 1998). For example, the weight-length relation (WLR) of a particular species is commonly used to estimate the mean weight for a given length group and to convert length observations into weights to provide a measure of the biomass (Froese 2006, Froese et al. 2011). Since stock assessment models and management for fisheries require information about body weight for estimation of biomass and regulation of catches, weight can be predicted from length using a weight-length relation (Froese et al. 2014). Furthermore, the weightlength relation allows the fish condition to be estimated and used in analyses of ontogenetic changes (Froese 2006, Ferraton et al. 2007) and for comparisons of intra- and inter-regional life-history traits (Morey et al. 2003, Barnes et al. 2011). The exponent $b$ from WLR can be used as a fundamental parameter to understand the structure of a fish population (Le Cren 1951, Froese 2006).

The ten fish species-Alcichthys alcicornis (Steindachner 1881); Cleisthenes pinetorum Jordan et Starks, 1904; Dasycottus setiger Bean, 1890; Gadus macrocephalus Tilesius, 1810; Glyptocephalus stelleri (Schmidt, 1904); Gymnocanthus herzensteini Jordan et Starks, 1904; Gymnocanthus intermedius (Temminck et Schlegel, 1843); Liparis punctulatus (Tanaka, 1916); Lycodes tanakae Jordan et Thompson, 1914; and Pseudopleuronectes herzensteini (Jordan et Snyder, 1901) - are among important commercial fishes in eastern Korean waters (Anonymous 2017). Although WLRs of several demersal fishes including 29 demersal fishes and commercial righteye flounders inhabiting eastern waters of Korea have been studied (Park and Huh 2015, Kwak and Park 2016), there is still insufficient information about WLR parameters for Korean fishes in this region. This study reports WLRs for ten fish species collected by bottom gill net and trammel net from the eastern coast of Korea. This paper represents the first step in the collation of biometric data and parameters in support of the future studies on somatic growth for Korean teleosts.

\section{MATERIAL AND METHODS}

Fish were sampled seasonally in each year between 2011 and 2017 off the eastern waters of Korea $\left(36^{\circ} 44^{\prime}-\right.$ $\left.36^{\circ} 48^{\prime} \mathrm{N}, 129^{\circ} 26^{\prime}-129^{\circ} 40^{\prime} \mathrm{E}\right)$ from depths between 50 and $150 \mathrm{~m}$ using both bottom gill net (75 m length, $2 \mathrm{~m}$ height, $90 \mathrm{~mm}$ mesh) and trammel net (90 m length, $2.8 \mathrm{~m}$ height, $600 \mathrm{~mm}$ and $85 \mathrm{~mm}$ mesh in outer and inner panels, respectively) on a commercial boat. The nets set for $24 \mathrm{~h}$ and samples were collected in the morning. Immediately after capture, individuals packed with ice and transported to the laboratory where total length (TL) and wet weight 
$(W)$ were measured to the nearest $0.1 \mathrm{~cm}$ and nearest 0.1 $\mathrm{g}$, respectively. All scientific names were verified using FishBase (Froese and Pauly 2018).

For each species, the allometric equation of weightlength function,

$$
W=a \mathrm{TL}^{b}
$$

was fitted to the data using linear regressions of $\log _{10^{-}}$ transformed data, where $W$ is the wet weight in $\mathrm{g}$, TL is the total length in $\mathrm{cm}$, and $a$ and $b$ are the intercept and allometric coefficient, respectively. Extreme outliers were removed before fitting the linear regression (Froese et al. 2011). The $95 \%$ confidence intervals (CI) of parameters $a$ and $b$ and the statistical significance level of $r^{2}$ were estimated using SYSTAT software (Systat version 18. SPSS Inc., USA). Because analysis of covariance (ANCOVA) was detected no significant differences in the slopes of weight-length regressions among seasons and years, WLRs were summarized for all seasons and years. Differences of $b$ values from the isometric value of 3 were tested using Student's $t$-test. An assumed significance level of 0.05 was used in the statistical analysis.

\section{RESULTS AND DISCUSSION}

Weight-length regressions were performed using 5884 specimens of the ten species belong to six families (Table 1). The estimated parameters $a$ and $b$ for the WLRs, along with the descriptive statistics by species, are given in Table 1. All the coefficients of WLRs were highly significant $(P$ $<0.05$ ), with $r^{2}$ values $>0.937$. The $r^{2}$ values ranged from 0.937 for Gymnocanthus intermedius to 0.986 for Liparis punctulatus. Estimated $b$ values ranged from 2.899 for Dasycottus setiger to 3.416 for Glyptocephalus stelleri.

The $b$ values of all species were within the expected range of 2.5 to 3.5 (Froese 2006). The $b$ values for eight species were found the higher end of the expected range, indicating a tendency towards positive allometry, which is in accordance with the majority of fish species because most large specimens were thicker than small conspecifics (Froese 2006), while those of Dasycottus setiger and Lycodes tanakae were shown negative allometry or isometry, respectively. The WLRs for Alcichthys alcicornis, Gymnocanthus herzensteini, Gymnocanthus intermedius, and Liparis punctulatus are firstly reported in this study. Our result also provides new maximum lengths for $G$. intermedius and L. punctulatus $(28.6 \mathrm{~cm}$ TL and $70.0 \mathrm{~cm}$ TL, respectively). Parameters of WLRs for remaining 6 species were available in FishBase (Froese and Pauly 2018). WLRs for the three flounder species, Cleisthenes pinetorum, Glyptocephalus stelleri and Pseudopleuronectes herzensteini have also been reported from the eastern Korean waters (Kwak and Park 2016). Although most of the previous listings of WLR parameters were similar, some descriptive statistics were unusual for $a$ and $b$ values, which might preclude direct comparisons with the results of our study. For example, the parameters

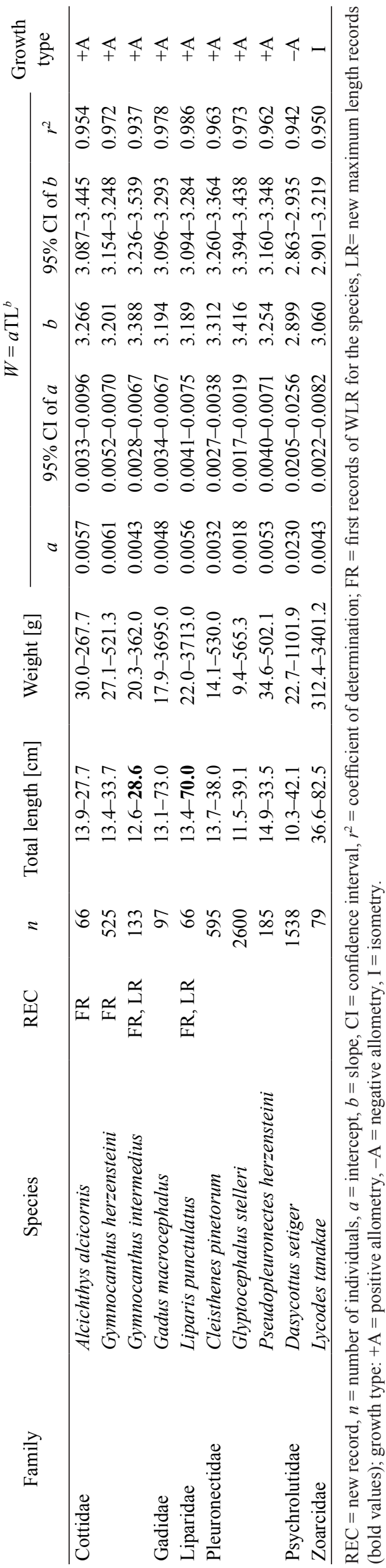


of $a$ and $b$ for $G$. stelleri from the North Pacific were not reliable due to abnormally high estimates (Fadeev 2005).

The WLRs obtained here were compared with the Bayesian estimates of WLRs in FishBase (Froese et al. 2014), and the values of intercept $a$ for each species were within the ranges expected for the species or the family and body shape where they belong. Thus, our estimates of the WLRs for the ten species are acceptable as valid WLR parameters.

In conclusion, this study provides WLRs of ten demersal fishes caught on the eastern Korean waters. Although some information already exists on these relations for Korean fishes, this study represents the first quantitative analysis of a set of body size and weight parameters for teleost species in eastern Korean waters. This research will contribute towards future stock assessment studies and can be useful for sustainable utilization and management of fishery resources in the region, and also for fishery biologists/managers in Korea.

\section{ACKNOWLEDGEMENTS}

We thank Sun Man Kwon, Moon Hee Han, Kang $\mathrm{Su}$ Seol, and Jong Won Park (Gangneung-Wonju National University, Korea) for assistance with sample measurements. We also thank the anonymous referees for their constructive criticism of the manuscript. This research was parts of the project entitled "Walleye Pollock stock management based on Marine Information \& Communication Technology" and "Long-term change of structure and function in marine ecosystems of Korea", funded by the Ministry of Oceans and Fisheries, Korea.

\section{REFERENCES}

Anonymous 2017. Fishery production survey. Korea Statistical Information Service (KOSIS). [Version 12/2017] www.kosis.kr

Barnes L.M., Gray C.A., Williamson J.E. 2011. Divergence of the growth characteristics and longevity of coexisting Platycephalidae (Pisces). Marine and Freshwater Research 62 (11): 1308-1317. DOI: 10.1071/MF11045

Fadeev N.S. 2005. Spravočnik po biologii i promyslu ryb severnoj časti Tihogo okeana. [Guide to biology and fisheries of fishes of the northern part of the Pacific Ocean.] TINRO-Centr, Vladivostok, Russia. [In Russian.]
Ferraton F., Harmelin-Vivien M., Mellon-Duval C., Souplet A. 2007. Spatio-temporal variation in diet may affect condition and abundance of juvenile European hake in the Gulf of Lions (NW Mediterranean). Marine Ecology Progress Series 337: 197-208. DOI: 10.3354/ meps337197

Froese R. 1998. Length-weight relationships for 18 lessstudied fish species. Journal of Applied Ichthyology 14 (1-2): 117-118. DOI: 10.1111/j.1439-0426.1998. tb00626.x

Froese R. 2006. Cube law, condition factor and weightlength relationships: History, meta-analysis and recommendations. Journal of Applied Ichthyology 22 (4): 241-253. DOI: 10.1111/j.1439-0426.2006.00805.X

Froese R., Pauly D. (eds.) 2018. FishBase. [Version 02/2018] www.fishbase.org

Froese R., Thorson J.T., Reyes R.B.jr. 2014. A Bayesian approach for estimating length-weight relationships in fishes. Journal of Applied Ichthyology 30 (1): 78-85. DOI: $10.1111 /$ jai.12299

Froese R., Tsikliras A.C., Stergiou K.I. 2011. Editorial note on weight-length relations of fishes. Acta Ichthyologica et Piscatoria 41 (4): 261-263. DOI: 10.3750/AIP2011.41.4.01

King M. 1995. Fisheries biology, assessment and management. Fishing News Books. Blackwell Science, Oxford, UK.

Kwak S.N., Park J.M. 2016. Length-weight and length-length relationships for six flounder species (Pleuronectiformes) from the eastern coast of Korea. Journal of Applied Ichthyology 32 (1): 160-162. DOI: 10.1111/jai.12932

Le Cren E.D. 1951. The length-weight relationship and seasonal cycle in gonad weight and condition in the perch (Perca fluviatilis). Journal of Animal Ecology 20 (2): 201-219. DOI: $10.2307 / 1540$

Morey G., Moranta J., Massuti E., Grau A., Linde M., Riera F., Morales-Nin B. 2003. Weight-length relationships of littoral to lower slope fishes from the Western Mediterranean. Fisheries Research 62 (1): 89-96. DOI: 10.1016/S0165-7836(02)00250-3

Park J.M., Huh S.H. 2015. Length-weight relations for 29 demersal fishes caught by small otter trawl on the south-eastern coast of Korea. Acta Ichthyologica et Piscatoria 45 (4): 427-431. DOI: 10.3750/ AIP2015.45.4.13

Received: 26 December 2017 Accepted: 27 March 2018 Published electronically: 30 June 2018 
